\title{
AGENCY COST PADA PERUSAHAAN KELUARGA DAN NON KELUARGA
}

\author{
Layyinaturrobaniyah \\ Rachmat Sudarsono \\ Desi Fitriyana \\ Fakultas Ekonomi dan Bisnis, Universitas Padjadjaran, Bandung \\ e-mail: callista_first@yahoo.com; rachmat.sudarsono@fe.unpad.ac.id \\ fitriyana.desi@gmail.com
}

\begin{abstract}
This study intends to find out how much influence the agency cost to company performance in Indonesia both companies to control the family and nonfamily firms. Proxy chosen in describing the agency cost are expense ratio and asset utilization ratio and for the measurement of company performance, represented by Tobin's $Q$ ratio. The study was conducted on 32 firms with family ownership structure and the 22 companies with non-family ownership structure listed on the Indonesia Stock Exchange (BEI) in the period 2008-2010. These results indicate that the expense ratio has a significant negative impact on company performance. For the asset utilization ratio has a significant positive impact on company performance. With the moderation effect of family ownership in the company can't weaken the negative effect of expense ratio as a proxy for agency cost to company performance. The results also showed that the presence of moderating effects of family ownership in the company can weaken the positive effect of asset utilization ratio as a proxy for agency cost to company performance.
\end{abstract}

Keywords: Agency Cost, Agency Conflict, Family Corporation, Tobin's Q ratio.

\begin{abstract}
Abstrak
Penelitian ini bertujuan untuk mengetahui seberapa besar pengaruh agency cost terhadap kinerja perusahaan pada perusahaan keluarga dan non keluarga. Agency cost dalam penelitian ini diproksikan dengan expense ratio dan asset utilization ratio, sementara itu kinerja perusahaan diproksikan dengan rasio Tobin's Q. Sampel dalam penelitian ini sebanyak 32 perusahaan dengan struktur kepemilikan keluarga dan 22 perusahaan dengan struktur kepemilikan non keluarga yang terdaftar di Bursa Efek Indonesia periode tahun 2008-2010. Dengan analisis regresi data panel diperoleh hasil bahwa expense ratio memiliki pengaruh negatif signifikan terhadap kinerja perusahaan. Sementara itu, untuk asset utilization ratio memiliki pengaruh positif terhadap kinerja perusahaan. Lebih lanjut, dengan efek moderasi, kepemilikan keluarga dapat memperlemah pengaruh negatif agency cost yang diproksikan dengan expense ratio dan dapat memperlemah pengaruh positif agency cost yang diproksikan dengan asset utilization ratio terhadap kinerja perusahaan.
\end{abstract}

Kata Kunci: Agency cost, Agency problem, Kepemilikan keluarga, Rasio Tobin's Q.

\section{PENDAHULUAN}

Struktur kepemilikan perusahaan-perusahaan di Indonesia sebagian besar adalah keluarga sebagai pemilik utamanya serta dikontrol oleh keluarga. Lebih dari $90 \%$ populasi perusahaan di Indonesia merupakan perusahaan keluarga dan dikendalikan oleh keluarga (Solomon, 2007; Djatmiko, 2011 dalam Hartini, 2011).
Susanto (2007) menyatakan bahwa penelitian di negara-negara yang lebih maju menunjukkan sebagian besar pendiri perusahaan keluarga tidak menginginkan keturunannya bekerja di perusahaan tersebut. Sedangkan di Indonesia berdasarkan hasil penelitian yang dilakukan The Jakarta Consulting Group yang dipublikasikan pada tahun 2006 terhadap 87 perusa- 
haan keluarga skala menengah ke atas yang tersebar di beberapa kota di Indonesia adalah bahwa mayoritas pendiri perusahaan keluarga ingin agar anak-anak mereka masuk kedalam perusahaan, dan respon dari anggota keluarga juga mereka memang menginginkan bekerja dalam perusahaan keluarga tersebut.

Keterlibatan keluarga dalam bisnis memiliki potensi yang dapat meningkatkan maupun menurunkan kinerja keuangan yang disebabkan oleh agency cost (Litz et al. 2004). Agency cost ini dapat timbul ketika perusahaan keluarga mempekerjakan pihak luar keluarga sebagai agen di perusahaan. Penelitian dari Litz et al. (2004) mengasumsikan bahwa perusahaan yang dikelola oleh keluarga akan memiliki tingkat agency cost sama dengan nol sesuai dengan penelitian dari Jensen dan Meckling (1976); Fama dan Jensen (1983); Ang et al. (2000).

Dalam teori keagenan Jensen dan Meckling (1976) menyatakan bahwa perusahaan dengan manajer sebagai pemegang saham tunggal (100\%) akan memiliki tingkat agency cost sama dengan nol. Hal ini juga didukung oleh hasil penelitian Ang et al. (2000) dengan kriteria kepemilikan saham di atas 50\% yang dimiliki oleh manajer atau satu keluarga tertentu yang menyatakan bahwa agency cost secara signifikan lebih tinggi bila orang luar (outsider) yang mengelola perusahaan daripada orang dalam (insider). Menurut teori Fama dan Jensen (1983) yang dikutip dari tulisan Muslimin (2009) masalah keagenan yang terjadi antara pemilik dengan manajemen perusahaan dapat ditekan atau diminimalisir dengan adanya keluarga yang menduduki salah satu jabatan dalam manajemen karena pengambilan keputusan dan kontrol dilakukan oleh agen yang sama yaitu anggota keluarga sehingga dapat meminimalisir agency cost yang muncul untuk memantau keputusan yang dilakukan. Dari teori yang dipaparkan di atas diduga perusahaan dengan konsentrasi kepemilikan keluarga dan terdapat keterlibatan keluarga di dalam perusahaannya dapat menekan konflik yang mungkin terjadi dan meminimalisir biaya yang timbul dari konflik tersebut. Pada kenyataannya perusahaan keluarga justru rentan akan konflik (Susanto, 2007). Konflik yang mungkin terjadi dalam perusahaan keluarga adalah konflik antara kepentingan bisnis dan keluarga, konflik antar anggota keluarga, dan konflik antara keluarga dan karyawan.

Berdasarkan pendahuluan diatas, maka dirumuskan masalah sebagai berikut: Apakah terdapat pengaruh agency cost yang diproksi kan oleh expense ratio terhadap kinerja perusahaan? Apakah terdapat pengaruh agency cost yang diproksikan oleh asset utilization ratio terhadap kinerja perusahaan? Apakah kepemilikan keluarga memoderasi pengaruh agency cost terhadap kinerja perusahaan?

Tujuan penelitian ini adalah ini untuk mengetahui pengaruh dari agency cost yang diproksikan oleh expense ratio terhadap kinerja perusahaan dan untuk mengetahui pengaruh dari agency cost yang diproksikan oleh asset utilization ratio terhadap kinerja perusahaan serta untuk mengetahui efek moderasi dari kepemilikan keluarga terhadap pengaruh negatif agency cost pada kinerja perusahaan. Hasil penelitian diharapkan dapat memberikan kontribusi dan tambahan informasi yang berguna perusahaan khususnya perusahaan keluarga dalam mempertimbangkan anggota keluarga sebagai agen dalam perusahaan.

\section{KAJIAN PUSTAKA}

Konsep agency theory merupakan hubungan atau kontrak antara principal dan agent. Dimana principal disini adalah pemegang saham dan yang dimaksud agent disini adalah satu orang atau lebih yang mengelola perusahaan (manajemen). Principal memperkerjakan dan mendelegasikan agent untuk melakukan tugas mengelola perusahaan untuk memenuhi kepentingan principal. Schroeder, Clark dan McCuller (1999) mendefinisikan agensi (agency) sebagai suatu hubungan melalui persetujuan antara dua pihak. Di satu pihak seorang manajer bertindak sebagai agent dan di lain pihak pemilik bertindak sebagai principal. Mereka memberikan asumsi dasar agency theory yang menyatakan bahwa individuindividu berusaha memaksimumkan utilitasnya masing-masing, sehingga hal ini akan mendorong kreasi dan inovasi untuk melakukan suatu pekerjaan.

Pada dasarnya agent dan principal berada pada posisi asymetric information dimana agent sebagai manajemen yang mengelola perusahaan memiliki lebih banyak informasi terkait perusahaan dibandingkan 
pemilik perusahaan (principal), sebagaimana yang dinyatakan oleh Ross (1973) dalam Litz et al. (2004) bahwa hubungan antara prinsipal dan agen selalu dihadapkan dengan penguasaan informasi yang tidak merata (asymetric information) dimana pengelola amanat selalu memiliki informasi yang lebih banyak dan mendalam tentang amanat yang dipikulnya. Kondisi yang tidak seimbang ini memberikan insentif pada pengelola untuk melakukan halhal yang menguntungkan mereka secara pribadi namun memberikan beban yang ditanggung oleh pemberi amanat. Tindakan ini sering disebut dengan moral hazard.

Berkaitan dengan masalah keagenan (agency problem), Schroeder, Clark dan McCuller (1999) berpendapat bahwa akan terjadi konflik kepentingan antara manajer dengan pemilik, dan konflik kepentingan tersebut muncul karena kepercayaan yang mengatakan bahwa manajer akan memaksimumkan utilitinya sendiri. Di lain pihak pemilik juga berkeinginan memaksimumkan keuntungan atau profitnya sendiri (Belkaoui, 2004).

Agency conflict terjadi manakala manajer cenderung membuat keputusan yang menguntungkan dirinya daripada kepentingan pemegang saham (Meckling 1976, Myers 1977) dalam Fachrudin (2009). Pendapat lainya mengenai masalah keagenan yang datang dari Godfrey (2000) menyatakan bahwa konflik kepentingan yang terjadi antara agent dan principal dapat menimbulkan masalah keagenan (agency problem). Untuk memonitor dan mengurangi agency problem ini perusahaan mengeluarkan biaya yang disebut biaya keagenan (agency cost).

Jensen dan Meckling (1976) menyatakan bahwa agency cost merupakan penjumlahan dari monitoring cost, bonding cost, dan residual losses. Dimana monitoring cost merupakan biaya yang timbul dan ditanggung oleh principal untuk mengawasi perilaku agent seperti penetapan jumlah kompensasi yang akan diberikan pada manajer. Kemudian yang kedua, bonding cost adalah biaya yang ditanggung oleh agen untuk memastikan bahwa mekanisme yang ada sesuai dengan kepentingan prinsipal seperti biaya yang dikeluarkan manajer untuk menyediakan laporan keuangan bagi pemegang saham. Ketiga, residual losess adalah biaya yang timbul dari kenyataan yang kadang kala tindakan manajer tidak sesuai dengan tujuan untuk memaksimumkan kepentingan prinsipal.

Dalam penelitiannya Ang et al. (2000) untuk mengukur tingkat agency cost perusahaan dapat digunakan dua alternatif rasio efisiensi yang sering digunakan dalam literatur akuntasi dan literatur ekonomi keuangan. Kedua rasio efisiensi ini adalah expense ratio dan asset utilization ratio. Expense ratio mengukur biaya keagenan berdasarkan rasio beban operasi terhadap total penjualan. Beban operasi merefleksikan diskresi manajerial dalam membelanjakan sumberdaya perusahaan.

Semakin tinggi beban diskresi manajerial maka semakin tinggi biaya keagenan yang terjadi (Faisal, 2005). Total asset turnover mengukur biaya keagenan berdasarkan tingkat perputaran aktiva (asset turnover) dan sebagai proksi asset utilization. Tingkat perputaran aktiva merupakan rasio antara total penjualan dengan total aktiva. Rasio ini digunakan untuk mengukur efisiensi penggunaan aktiva oleh manajemen. Semakin tinggi rasio ini maka semakin produktif aktiva tersebut digunakan untuk menciptakan nilai bagi pemegang saham (Faisal, 2005).

Susanto (2007) menyatakan perusahaan keluarga dicirikan terutama dengan kepemilikan dan keterlibatan yang signifikan dari keluarga dalam manajemen. Sementara itu, Donnelley (2002) menyatakan bahwa suatu organisasi dinamakan perusahaan keluarga apabila paling sedikit ada keterlibatan dua generasi dalam keluarga tersebut dan mereka mempengaruhi kebijakan perusahaan.

Dalam tulisannya Muslimin (2009) menggunakan kriteria perusahaan keluarga minimal $5 \%$ persen dari total saham dimiliki oleh keluarga tertentu atau jika kurang dari 5\% terdapat anggota keluarga yang mempunyai jabatan pada dewan direksi atau dewan komisaris perusahaan. Pemilihan kriteria ini berdasarkan definisi perusahaan keluarga dari penelitian-penelitian sebelumnya (Miller et al. 2007; Villalonga dan Amit, 2006; Claessens, 2000; Allen dan Panian, 1982; Perez dan Gonzales, 2006).

Definisi lain yang dinyatakan Muslimin (2009) dalam tulisannya berasal dari Barth et al. (2005) yang mengklasifikasikan perusahaan sebagai perusahaan keluarga apabila suatu keluarga minimal memiliki 33\% dari total saham perusahaan. Facio dan Lang 
(2002) mensyaratkan minimal $20 \%$ saham dikuasai oleh suatu keluarga tertentu untuk diklasifikasikan sebagai perusahaan keluarga.

Dalam perusahaan keluarga terdapat kecenderungan untuk mempekerjakan anggota keluarga sebagai agen dalam perusahaan. Dengan adanya keterlibatan anggota keluarga ini justru dapat memicu timbulnya agency conflict dalam perusahaan. Dalam perusahaan keluarga terkadang pemilik (principal) berharap dengan adanya keterlibatan keluarga dalam perusahaan maka anggota keluarga yang didelegasikan sebagai agen tersebut akan bersifat altruistik karena adanya kewajiban dari hubungan kekeluargaan tersebut yang mengikat moral pada berbagai budaya (Stewart, 2003) dalam Litz et al. (2004). Berdasarkan teori yang ada (Sculze et al. 2001, 2003) dalam Litz et al. (2004) menyatakan bahwa hubungan keluarga pada perusahaan keluarga dapat menciptakan agency problem yang unik, dimana hal ini bisa mendasari konflik nyang biasa terjadi pada perusahaan keluarga seperti adanya konflik karena adanya perbedaan pandangan antara pendiri perusahaan sebagai principal dengan generasi yang lebih muda sebagai agent dalam menjalankan bisnis.

Salah satu indikator dari nilai perusahaan yaitu rasio Tobin's $Q$ dimana rasio Tobin's Q adalah indikator untuk menilai kinerja perusahaan, khususnya tentang nilai perusahaan, yang menunjukkan suatu proforma manajemen dalam mengelola aktiva perusahaan. Nilai Tobin's Q menggambarkan suatu kondisi peluang investasi yang dimiliki suatu perusahaan (Lang et al. 1989) atau potensi peluang pertumbuhan perusahaan (Tobin dan Brainard, 1968; Tobin, 1969) dalam Sudiyatno dan Puspitasari, 2010.

\section{Hipotesis}

Berdasarkan rerangka pemilkiran diatas, maka penulis mengemukakan suatu hipotesis untuk identifikasi masalah dan tujuan penelitian sebagai berikut:

$\mathrm{H}_{1}$ : Agency cost yang diproksikan oleh expense ratio berpengaruh negatif terhadap kinerja perusahaan.

$\mathrm{H}_{2}$ : Agency cost yang diproksikan oleh asset utilization ratio berpengaruh positif terhadap kinerja perusahaan.
$\mathrm{H}_{3}$ : Kepemilikan keluarga memperlemah pengaruh agency cost terhadap kinerja perusahaan.

\section{METODE PENELITIAN}

Metode yang digunakan dalam penelitian ini adalah metoda deskriptif dengan pendekatan verifikatif. Dalam penelitian ini digunakan satu variabel terikat yaitu rasio Tobins $\mathrm{Q}$ dimana rasio ini merupakan rasio nilai pasar dari aset perusahaan dengan biaya penggantian aset perusahaan dan tiga variabel bebas yaitu expense ratio, asset utilization ratio, dan family firm dummy. Expense ratio merupakan perbandingan antara total beban yang harus ditanggung perusahaan terhadap total penjualan perusahaan sedangkan asset utilization ratio merupakan perbandingan antara total penjualan perusahaan terhadap total aset perusahaan.

Metode pemilihan sampel yang digunakan dalam penelitian ini adalah metoda purposive sampling yaitu sampel diambil dengan maksud dan tujuan tertentu berdasarkan kriteria yang ditetapkan. Kriteria-kriteria yang dijadikan dasar pemilihan sampel dalam penelitian ini adalah sebagai berikut: a) Perusahaanperusahaan yang terdaftar pada Bursa Efek Indonesia periode 2008 hingga 2010. b) Perusahaan memiliki laporan tahunan (annual repory yang berakhir tanggal 31 Desember dan mempublikasikan laporan keuangannya (financial report) untuk periode 2008-2010. c) Perusahaan yang bukan termasuk dalam kategori perusahaan keuangan (lembaga keuangan, asuransi dan bank). d) Perusahaan diklasifikasikan sebagai perusahaan keluarga apabila 5\% atau lebih saham yang dimiliki oleh suatu keluarga atau setidaknya ada keterlibatan dua orang keluarga atau lebih dalam perusahaan. Hal tersebut merujuk pada definisi perusahaan keluarga dan penelitian-penelitian sebelumnya. (Miller et al. 2007; Villalonga dan Amit, 2006; Claessens, 2000; Allen dan Panian, 1982; Perez dan Gonzales, 2006 dalam Muslimin, 2009).

Berdasarkan kriteria pemilihan sampel tersebut diperoleh sampel sebanyak 55 perusahaan dengan 32 sampel perusahaan yang diklasifikasikan ke dalam perusahaan keluarga dan 23 sampel perusahaan yang diklasifikasikan ke dalam perusahaan non keluarga. 
Tabel 1: Daftar Perusahaan dengan Kepemilikan Keluarga

\begin{tabular}{|c|c|c|c|}
\hline No. & Kode & Nama Perusahaan & Sektor \\
\hline 1. & ADRO & PT. Adaro Energy Tbk. & Pertambangan \\
\hline 2. & AKRA & PT. AKR Corporindo Tbk. & Bahan Kimia \\
\hline 3. & BATA & PT. Sepatu Bata Tbk. & Pakaian dan Produk tekstil \\
\hline 4. & BKSL & PT. Sentul City Tbk. & Real Estate dan Properti \\
\hline 5. & BLTA & PT. Berlian Laju Tanker Tbk. & Transportasi \\
\hline 6. & BRAM & PT. Indo Kordsa Tbk. & Otomotif \\
\hline 7. & BRNA & PT. Berlina Tbk. & Plastik \\
\hline 8. & BTEL & PT. Bakrie Telecom Tbk. & Telekomunikasi \\
\hline 9. & BUMI & PT. Bumi Resources Tbk. & Pertambangan \\
\hline 10. & CTRP & PT. Ciputra Property Tbk. & Real Estate dan Properti \\
\hline 11. & DPNS & PT. Duta Pertiwi Nusantara Tbk. & Bahan Perekat \\
\hline 12. & ELTY & PT. Bakrieland Development Tbk. & Real Estate dan Poperti \\
\hline 13. & GGRM & PT. Gudang Garam Tbk. & Rokok \\
\hline 14. & INDF & PT. Indofood Sukses Makmur Tbk. & Makanan dan Minuman \\
\hline 15. & INDR & PT. Indorama Syntetics Tbk. & Pakaian dan Produk tekstil \\
\hline 16. & KICI & PT. Kedaung Indah Can Tbk. & Produk Logam \\
\hline 17. & KIJA & PT. Jababeka Tbk. & Real Estate dan Properti \\
\hline 18. & KLBF & PT. Kalbe farma Tbk. & Farmasi \\
\hline 19. & MDRN & PT. Modern International Tbk. & Peralatan potografi \\
\hline 20. & MEDC & PT. Medco energi Internasional Tbk. & Pertambangan \\
\hline 21. & MYOR & PT. Mayora Indah Tbk. & Makanan dan Minuman \\
\hline 22. & NIPS & PT. Nipress Tbk. & Otomotif \\
\hline 23. & RALS & PT. Ramayana Lestari Sentosa Tbk. & Ritel \\
\hline 24. & SGRO & PT. Sampoerna Agro Tbk. & Agrobisnis \\
\hline 25. & SHID & PT. Hotel Sahid Jaya International Tbk. & Hotel \\
\hline 26. & SMSM & PT. Selamat Sempurna Tbk. & Otomotif \\
\hline 27. & TGKA & PT. Tigaraksa Satria Tbk. & Ritel \\
\hline 28. & TIRA & PT. Tira Austenite Tbk. & Manufaktur Logam \\
\hline 29. & TIRT & PT. Tirta Mahakam Resources Tbk. & Olahan Kayu \\
\hline 30. & TKIM & PT. Pabrik Kertas Tjiwi Kimia Tbk. & Kertas \\
\hline 31. & ULTJ & PT. Ultrajaya Milk Tbk. & Minuman \\
\hline 32. & UNSP & PT. Bakrie Sumatra Plantations Tbk. & Agrobisnis \\
\hline
\end{tabular}

Sumber: www.idx.co.id data diolah

Tabel 2: Daftar Perusahaan dengan Kepemilikan Non Keluarga

\begin{tabular}{|c|c|c|c|}
\hline No. & Kode & Nama Perusahaan & Sektor \\
\hline 1. & AKKU & PT. Alam Karya Unggul Tbk. & Plastik \\
\hline 2. & ARGO & PT. Argo Pantes Tbk. & Tekstil \\
\hline 3. & ARNA & PT. Arwana Citramulia Tbk. & Batu, clay dan gelas \\
\hline 4. & GJTL & PT. Gajah Tunggal Tbk. & Otomotif \\
\hline 5. & GMTD & PT. Gowa Makasar Tourism Development Tbk. & Real estate dan Property \\
\hline 6. & GMCW & PT. Grahamas Citrawisata Tbk. & Hotel dan Travel \\
\hline 7. & HERO & PT. Hero Supermaket Tbk. & Ritel \\
\hline 8. & INAF & PT. Indofarma Tbk. & Farmasi \\
\hline 9. & INDX & PT. Tanah Laut Tbk. & Transportasi \\
\hline 10. & INRU & PT. Toba Pulp Lestari Tbk. & Kertas \\
\hline 11. & INTP & PT. Indocement Tunggal Prakarsa Tbk. & Semen \\
\hline 12. & ITMA & PT. Sumber Energi Andalan Tbk. & Pertambangan \\
\hline 13. & ITMG & PT. Indo Tambangraya Megah Tbk. & Pertambangan \\
\hline 14. & JPFA & PT. JAPFA Tbk. & Peternakan \\
\hline 15. & LION & PT. Lion Metal Works Tbk. & Logam \\
\hline 16. & LPCK & PT. Lippo Cikarang Tbk. & Real estate dan Property \\
\hline 17. & LPPF & PT. Matahari Departement Store Tbk. & Ritel \\
\hline 18. & PLIN & PT. Plaza Indonesia Realty Tbk. & Hotel dan Travel \\
\hline 19. & SONA & PT. Sona Topas Tourism Industry Tbk. & Hotel dan Travel \\
\hline 20. & TLKM & PT. Telekomunikasi Indonesia & Telekomunikasi \\
\hline 21. & UNIC & PT. Unggul Indah Cahaya Tbk. & Kimia \\
\hline 22. & UNVR & PT. Unilever Tbk. & Consumer Good \\
\hline 23. & UNTX & PT. Unitex Tbk. & Tekstil \\
\hline
\end{tabular}

Sumber: www.idx.co.id data diolah 
Untuk data perusahaan yang dikatagorikan ke dalam perusahaan non keluarga, penulis mengklasifikasikannya berdasarkan kepemilikan perusahaan yang didalamnya tidak ada kontrol dan kepemilikan saham yang dominan oleh suatu keluarga.

Jenis data yang digunakan dalam penelitian ini adalah data sekunder dimana data sekunder dan data diperoleh dari website resmi Bursa Efek Indonesia (www.idx.co.id). Data yang digunakan dalam penelitian ini berdasarkan waktu pengumpulannya merupakan data panel yang biasa disebut juga data longitudinal atau data runtun waktu silang (cross-sectional time series), dimana banyak kasus (orang, perusahaan, negara dan lain-lain) yang diamati pada dua periode waktu atau lebih yang diindikasikan dengan penggunaan data time series. Data panel menjelaskan dua infomasi yaitu informasi cross-section pada perbedaan antar subjek, dan informasi time series yang merefleksikan perubahan pada subjek waktu. Ketika kedua informasi tersebut tersedia maka analisis data panel dapat digunakan.

\section{HASIL ANALISIS}

Dalam penelitian ini digunakan data panel untuk itu dalam mengolah data panel terdapat dua model yang dapat digunakan untuk menganalisis data panel yaitu fixed effect model dan random effect model. Untuk menentukan model yang digunakan maka dapat dilakukan uji Hausman terlebih dahulu. Setelah dilakukan uji Haussman dan hasilnya menolak Ho pada tingkat signifikansi 5\% maka dalam penelitian ini model yang digunakan adalah fixed effect model. Dalam penelitian ini digunakan metode Generalized Least Square. Dalam metode GLS ini masalah heterokedastisitas dan autokorelasi yang biasa terjadi pada data panel dapat diatasi. Menurut Gujarati (2003) salah satu perlakuan yang dapat dilakukan untuk mengatasi masalah autokorelasi dan heterokedastisitas adalah dengan menggunakan metode Generalized Least Square. Berikut model data panel yang digunakan dalam penelitian ini dan hasil regresi dari model tersebut.

Dari hasil pengujian pada Tabel 3 terlihat bahwa variabel expense ratio memiliki koefisien negatif sebesar 0,350782 yang berarti berpengaruh negatif terhadap kinerja perusahaan dan signifikan pada alpha $1 \%$ yang berarti bahwa setiap kenaikkan $1 \%$ expense ratio akan menurunkan nilai perusahaan sebesar 0,350782. Hal ini sesuai dengan hipotesis expense ratio berpengaruh negatif terhadap kinerja perusahaan.

Tabel 3: Hasil Estimasi Pengujian Hipotesis

$$
\begin{aligned}
Q_{i t} & =\alpha_{0}+\beta_{1} E R_{i t}+\varepsilon_{i t} \\
Q_{i t} & =\alpha_{0}+\beta_{1} E R_{i t}+\beta_{2} \text { D.BOPO.ER } R_{i t}+\varepsilon_{i t} \\
Q_{i t} & =\alpha_{0}+\beta_{1} E R_{i t}+\beta_{2} \text { D.FAM.ER } i t+\varepsilon_{i t} \\
Q_{i t} & =\alpha_{0}+\beta_{1} A U R_{i t}+\varepsilon_{i t} \\
Q_{i t} & =\alpha_{0}+\beta_{1} A U R_{i t}+\beta_{2} \text { D.FAM.AUR } i t+\varepsilon_{i t} \\
Q_{i t} & =\alpha_{0}+\beta_{1} A U R_{i t}+\beta_{2} \text { D.FAM.AUR } R_{i t}+\beta_{3} \text { D.AGE.AUR } R_{i t}+\varepsilon_{i t} \\
Q_{i t} & =\alpha_{0}+\beta_{1} E R_{i t}+\beta_{2} A U R_{i t}+\beta_{3} \text { D.FAM.ER } R_{i t}+\beta_{4} \text { D.FAM.AUR }{ }_{i t}+\varepsilon_{i t}
\end{aligned}
$$

\begin{tabular}{lccccccc}
\hline \multicolumn{1}{c}{ Variabel } & Model 4.1 & Model 4.2 & Model 4.3 & Model 4.4 & Model 4.5 & Model 4.6 & Model 4.7 \\
\hline ER & $-0.350782 * * *$ & $-0.561770 * * *$ & -0.060183 & & & -0.871411 \\
D.BOPO.ER & & $-0.114632 * * *$ & & & & & \\
D.FAM.ER & & & $-1.385434 * * *$ & & & & 0.305544 \\
AUR & & & & $1.580509 * * *$ & $1.892079 * * *$ & $1.936486 * * *$ & $1.042844 * *$ \\
D.FAM.AUR & & & & & $-0.486482 * * *$ & $-0.462274 * * *$ & $-0.998440 *$ \\
D.AGE.AUR & & & & & $-0.589537 * * *$ \\
$\mathrm{R}^{2}$ & 0.999988 & 0.999975 & 0.999977 & 0.913180 & 0.414778 & 0.524246 & 0.082533 \\
Adj. $\mathrm{R}^{2}$ & 0.999976 & 0.999948 & 0.999952 & 0.913180 & 0.409257 & 0.515184 & 0.046903 \\
\hline
\end{tabular}

\footnotetext{
*** signifikan pada $\alpha 1 \%$, ** signifikan pada $\alpha 5 \%$, * signifikan pada $\alpha 1 \%$
} 
Dengan adanya kontrol variabel dummy $\mathrm{BO} / \mathrm{PO}$ hasil penelitian menunjukan bahwa perusahaan yang mampu mengontrol biaya operasionalnya untuk meningkatkan laba perusahaan dimana perubahan penambahan pendapatan operasional masih lebih besar daripada perubahan penambahan pendapat operasional atau dengan kata lain marginal revenue masih lebih besar daripada marginal cost maka expense ratio dapat berpengaruh negatif terhadap kinerja perusahaan. Hal ini terlihat dari variabel dummy $\mathrm{BO} / \mathrm{PO}$ pada tabel di atas memiliki koefisien negatif sebesar 0,114632 dan signifikan pada alpha $1 \%$.

Dari hasil tabel 1 terlihat bahwa dengan adanya efek pemoderasi kepemilikan keluarga dapat mengubah pengaruh expense ratio terhadap kinerja perusahaan. Dengan adanya efek pemoderasi kepemilikan keluarga tidak dapat memperlemah pengaruh negatif agency cost terhadap kinerja perusahaan keluarga yang terlihat di tabel hasil 1 bahwa expense ratio tanpa ada efek pemoderasi kepemilikan keluarga berpengaruh negatif dan signifikan. Saat ada efek pemoderasi kepemilikan keluarga koefisien dari expense ratio tetap konsisten negatif sebesar 0,060183. Dengan adanya efek pemoderasi kepemilikan keluarga tidak memperlemah pengaruh expense ratio terhadap kinerja sehingga hasil estimasi model 4.3 menunjukkan hasil yang tidak sesuai dengan hipotesis.

Untuk variabel asset utilization ratio dari hasil estimasi model 4.4 terlihat bahwa variabel asset utilization ratio memiliki koefisien positif sebesar 1,580509 yang berarti berpengaruh positif terhadap kinerja perusahaan dan signifikan pada alpha $1 \%$ maka setiap kali terjadi kenaikan asset utilization ratio sebesar $1 \%$ akan menaikkan nilai Tobins Q sebagai nilai perusahaan sebesar 1,580509. Hal ini sesuai dengan hipotesis asset utilization ratio berpengaruh positif terhadap kinerja perusahaan.

Selain itu, dari hasil tabel 3 terlihat bahwa dengan adanya efek pemoderasi kepemilikan keluarga dapat merubah pengaruh asset utilization ratio terhadap kinerja perusahaan. Efek pemoderasi kepemilikan keluarga dapat memperlemah pengaruh positif asset utilization ratio terhadap kinerja yang terlihat dari koefisien variable dummy kepemilikan keluarga memiliki koefisien negatif sebesar 0,486482 dan signifikan pada alpha $1 \%$. Dengan adanya efek pemoderasi kepemilikan keluarga dapat memperlemah pengaruh positif asset utilization ratio terhadap kinerja sehingga yang terlihat dari penurunan koefisien asset utilization ratio akibat adanya efek pemoderasi kepemilikan keluarga.

Pada hasil estimasi model 4.6 terlihat juga pengaruh asset utilization ratio terhadap kinerja perusahaan yang dimoderasi oleh usia perusahaan. Variabel interaksi antara variable dummy usia perusahaan dengan asset utilization ratio memiliki koefisien negatif sebesar 0,589537 yang berarti bahwa hasil ini sesuai dengan hipotesis perusahaan dengan usia lebih muda memilki asset utilization ratio lebih rendah dibandingkan perusahaan yang lebih lama berdiri.

Sementara itu, hasil estimasi model 4.7 pengujian persamaan regresi agency cost yang diproksikan dengan expense ratio dan asset utilization ratio terhadap kinerja perusahaan yang diwakili oleh rasio nilai perusahaan terhadap total aktiva yaitu rasio Tobin's $\mathrm{Q}$, variabel expense ratio mempunyai koefisien negatif sebesar 0,871411 dan tidak signifikan pada alpha $1 \%, 5 \%$ dan $10 \%$. Untuk variabel independen kedua yaitu asset utilization ratio, variabel ini memiliki koefisien positif sebesar 1,042844 dan signifikan pada alpha 5\% yang berarti bahwa asset utilization ratio berpengaruh positif terhadap kinerja perusahaan (Tobins Q). Hasil ini mendukung hipotesis kedua yang menyatakan bahwa asset utilization ratio berpengaruh positif terhadap kinerja perusahaan (Tobins Q).

Variabel ketiga yang coba dinteraksikan dengan nilai perusahaan (Tobins Q) yaitu variabel moderasi. Variabel moderasi yang digunakan disini adalah variabel family firm dummy. Dimana variabel moderasi memiliki sifat yang dapat memperkuat atau memperlemah hubungan antara variabel expense ratio dan nilai perusahaan (Tobins Q). Dari hasil tabel 4.7 terlihat bahwa koefisien variabel interaksi tersebut nilai negatif sebesar 0.305544 dan tidak signifikan pada alpha 1\%, 5\% dan $10 \%$. Interaksi variabel moderasi berikutnya adalah antara variabel asset utilization ratio dengan variabel family firm dummy. Koefisien dari interaksi kedua variabel ini terhadap nilai perusahaan (Tobins Q) dapat terlihat dari tabel 
4.3 yakni sebesar - 0,998440 dan signifikan pada alpha $10 \%$.

Dari hasil estimasi model 4.7 terlihat bahwa variabel expense ratio dan variabel inte raksi antara variabel expense ratio dan variabel moderasi kepemilikan keluarga menunjukkan hasil yang tidak signifikan sedangkan variabel asset utilization ratio dan variabel interaksi antara variabel asset utilization ratio dengan varibel moderasi kepemilikan keluarga menunjukkan hasil yang signifikan pada alpha 5\% dan $10 \%$ maka terlihat bahwa variabel asset utilization ratio yag memberikan kontribusi pengaruh lebih besar terhadap kinerja perusahaan. Dari table 4.3 dapat diindikasikan bahwa adanya kepemilikan dan keterlibatan keluarga dalam perusahaan untuk perusahaanperusahaan di Indonesia justru meningkatkan agency cost perusahaan keluarga dan menurunkan kinerja perusahaan. Dengan kata lain perusahaan non keluarga memilki kinerja lebih baik dibandingkan kinerja perusahaan keluarga.

\section{PEMBAHASAN}

\section{Pengaruh Expense Ratio terhadap Kinerja Perusahaan (H1)}

Dari hasil yang telah diteliti, penelitian menunjukkan bahwa terdapat pengaruh negative dan signifikan dari variabel expense ratio terhadap kinerja perusahaan (rasio Tobins Q) dan sesuai dengan hipotesis pertama. Artinya, perusahaan dengan expense ratio yang tinggi mengindikasikan kurang baiknya manajemen perusahaan dalam mengelola biaya operasinalnya untuk memperoleh pendapatan operasional dan terdapat inidikasi bahwa adanya kecurangan manajemen yang disembunyikan dalam penggunaan biaya-biaya operasional perusahaan yang menyebabkan tingginya agency cost dan penurunan kinerja perusahaan.

\section{Pengaruh Asset Utilization Ratio terhadap Kinerja Perusahaan (H2)}

Hasil penelitian ini mendukung teori tentang agency cost yang diproksikan dengan asset utilization ratio yaitu berpengaruh positif terhadap kinerja perusahaan. Asset utilization ratio sebagai proksi agency cost dapat meningkatkan kinerja perusahaan ketika tingkat kinerja perusahaan dalam pengelolaan aktiva dilakukan secara efisien oleh manajemen perusahaan yang menunjukkan tidak adanya kesalahan atau kelalaian manajemen dalam mengelola aktiva perusahaan guna menciptakan nilai bagi perusahaan. Sehingga hasil ini mendukung hipotesis kedua bahwa asset utilization ratio berpengaruh positif terhadap kinerja perusahaan.

\section{Efek Moderasi Variabel Kepemilikan Keluarga (H3)}

Kepemilikan Keluarga Memperlemah Pengaruh Negatif Expense Ratio terhadap Kinerja Perusahaan

Hasil penelitian menunjukkan bahwa dengan adanya kepemilikan keluarga dalam perusahaan tidak memperlemah hubungan negatif agency cost terhadap kinerja karena expense ratio yang semula memiliki pengaruh negatif terhadap Tobins Q akan bergerak semakin negatif atau dengan kata lain pengaruh negatifnya bertambah dengan adanya kepemilikan keluarga sehingga nilai Tobins $\mathrm{Q}$ perusahaan keluarga dapat lebih rendah dibandingkan perusahaan non keluarga. Hal ini berarti expense ratio sebagai proksi agency cost tidak dapat menunujukkan bahwa agency cost di perusahaan keluarga akan lebih rendah dibandingkan perusahaan non keluarga.

Sesuai dengan hasil penelitian Ang et. al (2000) yang menunjukkan bahwa agency cost akan lebih rendah pada perusahaan yang dikelola oleh insider dibandingkan perusahaan yang dikelola oleh outsider. Selain itu Jensen dan Meckling (1976) menyatakan bahwa perusahaan dengan struktur kepemilikan tunggal $100 \%$ akan memiliki tingkat agency cost yang nol. Hasil penelitian ini menunjukan hal yangberbeda dari hasil penelitian Ang et al. (2000) dan Jensen dan Meckling (1976).

Ketika tidak ada kontrol keluarga dalam perusahaan expense ratio sebagai proksi agency cost berpengaruh negatif terhadap kinerja yang berarti hasil penelitian ini sesuai dengan teori yang menyatakan bahwa expense ratio berpengaruh negatif terhadap kinerja perusahaan. Ketika ada keterlibatan keluarga dalam perusahaan maka perusahaan keluarga akan memiliki expense ratio yang lebih rendah dan kinerja lebih rendah. Hal ini mengindikasikan terdapat konflik kepentingan antara manajer dengan pemegang saham yang 
sebenarnya memiliki hubungan keluarga dan menunjukkan bahwa manajemen dalam perusahaan keluarga kurang lebih mampu mengontrol biaya operasional sehingga kinerja perusahaan keluarga tidak lebih baik daripada kinerja perusahaan non keluarga. Konflik keagenan yang mungkin terjadi perusahaan keluarga ini adalah penggunaan hak aliran kas dimana bisa jadi manajer yang merupakan anggota keluarga pemilik perusahaan menetapkan kebijakan seperti penentuan gaji yang tidak sesuai sehingga agency cost meningkat. Hal ini tidak sesuai dengan hasil penelitian Anderson dan Reeb (2001) yang menunjukkan bahwa perusahaan keluarga lebih profitable dan memiliki nilai yang lebih tinggi dibandingkan perusahaan non keluarga. Hasil pertama ini tidak sesuai dengan hipotesis ke tiga yang menyebutkan bahwa kepemilikan keluarga memperlemah pengaruh negatif agency cost terhadap kinerja.

\section{Kepemilikan Keluarga Memperlemah Pengaruh Positif Asset Utilization Ratio terhadap Kinerja Perusahaan}

Hasil kedua dari efek moderasi kepemilikan keluarga menyatakan bahwa pengaruh kepemilikan keluarga memperlemah hubungan positif agency cost yang diproksikan oleh asset utilization ratio terhadap kinerja perusahaan. Dengan adanya kepemilikan keluarga ini nilai asset utilization ratio dalam perusahaan menjadi lebih rendah, sehingga diindikasikan dalam perusahaan keluarga terdapat penggunaan aktiva ataupun sumberdaya perusahaan yang tidak efisien yang bisa jadi aktiva atau sumberdaya tersebut dimanfaatkan secara pribadi oleh manajer untuk kepentingan pribadi dimana agen tersebut adalah keluarga dari pemilik perusahaan tersebut.

Dengan adanya penyalahgunaan hak kontrol perusahaan oleh manajer dalam perusahaan keluarga yang dimungkinkan adalah penggunaan aset ataupun sumberdaya perusahaan oleh agen (manajer) ini akan meningkatkan agency cost perusahaan keluarga sehingga asset utilization ratio perusahaan keluarga menurun dan kinerja perusahaanpun menurun dan pada akhirnya kinerja perusahaan keluarga lebih rendah dibandingkan perusahaan non keluarga.

Sculze et al. $(2001,2003)$ menyatakan bahwa adanya keterlibatan keluarga dalam perusahaan justru menciptakan agency problem yang unik yang mungkin sulit untuk dipecahkan sehingga agency cost akan lebih tinggi diperusahaan keluarga. Hasil penelitian ini menyatakan bahwa efek moderasi kepemilikan keluarga memperlemah pengaruh positif asset utilization ratio sebagai proksi agency cost terhadap kinerja perusahaan.

\section{Usia Perusahaan Memperlemah Pengaruh Positif Asset Utilization Ratio terhadap Kinerja Perusahaan}

Perusahaan yang lebih lama berdiri dan perusahaan yang baru berdiri tentu akan memiliki tingkat asset utilization ratio yang berbeda. Perusahaan lama tentunya relatif akan lebih tinggi tingkat asset utilization ratio yang dimilikinya karena salah satu faktornya adalah aset-aset perusahaan yang sudah mengalami banyak depresiasi dan diperlukan penggantian yang lebih cepat. Perusahaan yang baru berdiri akan memiliki tingkat asset utilization yang lebih rendah dibandingkan perusahaan yang lebih lama berdiri sehingga perusahaan baru cenderung memiliki kinerja yang lebih rendah dibandingkan perusahaan yang sudah lama berdiri.

Dari hasil penelitian terlihat bahwa usia perusahaan memperlemah pengaruh positif asset utilization ratio terhadap kinerja perusahaan. Perusahaan dengan usia yang relatif baru memiliki tingkat asset utilization ratio yang lebih rendah dibandingkan perusahaan yang lebih lama berdiri yang kemudian berdampak pada kinerja perusahaan. Tentunya perusahaan yang tergolong baru memiliki kinerja yang lebih rendah dibandingkan dengan perusahaan yang lebih lama berdiri ketika dilihat dari pengaruh positif asset utilization ratio terhadap kinerja perusahaan.

\section{PENUTUP}

Berdasarkan analisis data dan pembahasan yang dilakukan, dapat diambil kesimpulan bahwa hasil penelitian dengan variabel independen expense ratio dan asset utilization ratio sesuai dengan teori dan hipotesis. Expense Ratio sebagai proksi agency cost berpengaruh negatif terhadap kinerja perusahaan. Kemudian Asset utilization ratio sebagai proksi agency cost berpengaruh positif terhadap kinerja perusahaan. Untuk hasil penelitian yang ketiga 
tidak sesuai dengan hipotesis dimana Kepemili kan keluarga tidak memperlemah pengaruh negatif agency cost yang diproksikan oleh expense ratio terhadap kinerja dan kepemilikan keluarga juga dapat memperlemah pengaruh positif asset utilization ratio sebagai proksi agency cost terhadap kinerja perusahaan. Untuk pengaruh asset utilization ratio terhadap kinerja dapat dipengaruhi juga oleh usia perusahaan. Dalam perusahaan yang tergolong masih baru tingkat asset utilization ratio lebih rendah dibandingkan perusahaan lama sehingga mengindikasikan bahwa perusahaan baru memiliki tingkat agency cost lebih tinggi dengan kinerja yang lebih rendah dibandingkan perusahaan yang sudah lebih lama berdiri.

Dalam penelitian sampel yang digunakan hanya 54 perusahaan dengan periode penelitian tiga tahun. Untuk penelitian selanjutnya disarankan untuk menambahkan sampel dan periode penelitian jika memungkinkan agar tidak terjadi bias dan dapat memperkuat hasil penelitian. Bagi perusahaan keluarga sebaiknya mempertimbangkan kontrol keluarga dalam perusahaan yang dapat menimbulkan lebih banyak agency problem dalam perusahaan yang dapat mempengaruhi kinerja perusahaan. Selain itu, penelitian ini menginformasikan bahwa terdapat banyak variabel yang dapat menjelaskan agency cost yang terjadi dalam perusahaan. Jadi, baik manajer maupun investor dapat mempertimbangkan variabel-variabel tersebut untuk membuat keputusan terbaik agar dapat mengurangi konflik kepentingan dan dapat meningkatkan kinerja perusahaan.

\section{DAFTAR PUSTAKA}

Ajija, Shochrul R., Sari, Diah W., dan Setianto, Rahmat H. 2011. Cara Cerdas Menguasai Eviews. Jakarta. Salemba Empat.

Aminatuzzahra. 2010. Analisis Pengaruh Current Ratio, Debt to Equity Ratio, Total Asset Tunrover, Net Profit Margin terhadap ROE. Tesis FE UNDIP, Semarang.

Anderson, Ronald. and D. Reeb. 2003. Founding-Family Ownership and Firm Performance: Evidence from the S\&P 500. Journal of Finance. 58. 13011328.
Ang, James. S. Cole., Rebel. A., and L.J. Wuh. 2000. Agency Cost and Ownership Structure. The Journal of Finance. Vol LV, No. 1. 81-106.

Arifin, Zaenal. 2004. Solusi Masalah Agensi Perusahaan Publik di Indonesia: Pendekatan Game-Modeling dan Pendekatan Positif Empiris. Jurnal Siasat Bisnis. No. 9 Vol. 1.

Belkaoui, A. Riahi. 2004. Accounting Theory Fifth Edition. Cengage Learning EMEA.

Chrisman, James. J., Chua, Jess. H. and Litz, Reginald. A. 2004. Comparing the Agency Cost of Family and NonFamily Firms: Conseptual Issues and Exploratory Evidence. Entrepeneurship Theory and Practise.

Donnelley, Robert G. 1964. The Family Business. Harvard Business Review. The President and Fellows of Harvard College. 93-105.

Fachrudin, K. Amalia. 2011. Analisis Pengaruh Struktur Modal, Ukuraan Perusahaan dan Agency Cost terhadap Kinerja Perusahaan. Jurnal Akuntansi dan Keuangan. Vol 13 (1). 37-47.

Faisal. 2005. Analisis Agency Cost, Struktur Kepemilikan, dan Mekanisme Corporate Governance. Jurnal Riset Akuntansi Vol. 8 (2).

Fama, Eugene F. and Jensen, Michael C. 1983. Separation of Ownership and Control. Journal of Law and Economic, 26.

Godfrey, J., Allan Hodgson. and Scott Holmes. 2000. Accounting Theory. USA. Prentice Hall International Inc.

Hartini, J. S. 2011. Pengaruh Penurunan Konsentrsi Kepemilikan Saham Keluarga Terhadap Kinerja Perusahaan. Skripsi Fakultas Ekonomi Universitas Diponogoro.

Jensen, M.C. and Meckling, William. H. 1976. Theory of the Firm: Managerial Behavior, Agency Cost and Qwnership Structure. Journal of Financial Economics. Vol. 3 (4). 305-360. 
Meythi. 2005. Konflik Keagenan: Tinjauan Teoritis dan Cara Menguranginya. Jurnal Ilmiah Akuntansi. Bandung. Universitas Kristen Maranatha.

Mojtahedzadeh, V. and Nahavandi, N. N. A. Pour. 2011. FCF Agency Cost, Earning Management, and Investor Monitoring. Al-Zahra University Faculty of Social and Sciences and Econimic.

Muslimin, M. Ikhwan. 2009. Analisis Pengaruh Struktur Kepemilikan, Kepemimpinan dan Perwakilan Keluarga dalam Perusahaan Terhadap Kinerja Keuangan Perusahaan. Skripsi Fakultas Ekonomi Universitas Indonesia.

Schroeder, C. and McCullers. 1999. Accounting Theory: Text and Readings. $5^{\text {th }}$ edition. New York. Jhon Willey and Sons, Inc.
Sudiyatno, B dan E. Puspitasari. 2010. Tobin;s Q dan Altman Z-Score Sebagai Indikator Pengukuran Kinerja Perusahaan. Kajian Akuntansi. Vol. 2 (1). 9-21.

Susanto, A. B. 2007. World Class Family Business: Membangun Bisnis Keluarga Berkelas Dunia. Jakarta. Mizan

Wang, G. Yungcih. 2010. The Impacts of Free Cash Flows and Agency Cost on Firm Performance. Journal Service Sciences and Management. 3. 408-418.

Widya, Elvarazke. 2011. Pengaruh Expense Ratio, Turnover Ratio, Ukuran Reksadana dan Cash Flow Terhadap Kinerja Reksadana. Skripsi FE UNDIP, Semarang. 